\title{
Preparing ECE Students for Research Career in Nanotechnology via Track Program
}

\author{
Maher E. Rizkalla ${ }^{1,2}$ and Mangilal Agarwal $^{2}$ \\ ${ }^{1}$ Department of Electrical and Computer Engineering \\ ${ }^{2}$ Integrated Nanosystems Development Institute (INDI) \\ Indiana University-Purdue University Indianapolis, Indianapolis, Indiana
}

\begin{abstract}
This paper details the research participation of undergraduate students from the freshman to the senior year. Four courses were designated to prepare students for a nanotechnology research career. New modes of instructions leading to research participation followed in this curriculum have been reported. This covers integration of knowledge, just in time approach, and project portfolio based curriculum. Courses developed in this track emphasize research and applications in health sciences and renewable energy areas. The structure of the track program was presented before with emphasis on the senior level courses of the track. The work in this paper, however, emphasizes research participation in nanotechnology of the junior students within the electrical engineering, computer engineering, and mechanical engineering disciplines. The multidisciplinary components in nanotechnology research topics were attractive to students to work in team. The topics covered in this course included nanotechnology applications in diabetes, cancer research, and neurosciences. Lecture materials were all from up-to-date research papers, and can be altered with the course updates. Students registered for this course were required to emphasize two research topics seven week each, and prepare research posters in a research day where industrial representatives are invited to participate in the discussions with students. Students who completed this course were interested to continue with nanotechnology individual research and get enrolled in upper level courses.
\end{abstract}

The course starts with introducing students to the nanotechnology applications in various fields, including environment, society, consumer electronics, computers, health sciences, optics, electromagnetics, energy, and medical imaging. The course then introduces students to research issues emphasizing health sciences and renewable energy. Students will be required to expand their research to cover in depth one or two research issues that fall within their interests. In the research projects, students work in team, two students/team, and assignment is given to bath to share the contribution of the project.

Submitted on April $27^{\text {th }}, 2015$. The authors are with the School of Engineering and Technology at Indiana University Purdue University Indianapolis. The project was partially funded by the NSF NUE program grant 1042110.

Dr. Maher Rizkalla is a Professor \& Associate Chair of Department of Electrical and Computer Engineering and Member of Integrated Nanosystems Development Institute (INDI) at IUPUI, 723W Michigan St. Indianapolis, IN 46202 USA (email:mrizkall@iupui.edu)

Dr. Mangilal Agarwal is a Associate Director for Research Development and Director of Integrated Nanosystems Development Institute (INDI) at IUPUI.
The course was assessed with student satisfaction, and the objectives and the outcomes of the course were met.

Index Terms - undergraduate track, research career in nanotechnology, undergraduate research projects, multidisciplinary, innovation.

\section{INTRODUCTION}

Q ngineering major is considered in many disciplines as applied sciences where math and sciences knowledge are applied into real engineering products. Near $25 \%$ of engineering curriculum is covered from Math and Sciences course. Big emphases on the engineering programs are invested in mathematical and computer models, a very important element in engineering research. This emphasis assists undergraduate students with integrating knowledge from math and sciences into engineering system modeling. These systems may range from the device level to the system level. Classroom engineering instructions provide engineering students with research tools, including hands on practical models, mathematics models, and computer models. Software engineering is an integral component in the $\mathrm{EE}, \mathrm{CmpE}$, and ME curricula. These tools equip engineering students with research foundation. Undergraduates at Indiana University Purdue University Indianapolis (IUPUI) team up with graduate mentors, to explore research hypothesis in various areas.

At IUPUI, undergraduate students are engaged in research at early stages in the curriculum via individual research courses, multidisciplinary research courses, and industrial based research/design courses. Undergraduate research has become a part of the educational culture. They are given plenty of opportunities to apply math and sciences into engineering curricula.

Undergraduate research opportunities at IUPUI lie on the faculty research expertise. One of the research areas emphasized in the past 5 years was nanotechnology, where engineering and sciences faculty members integrating their efforts towards new engineering/science applications. Research topics range from bioengineering/biosensors, solid state nanotechnology and molecular devices, and nanomaterials. There are two areas of concentration 
emphasized by the Integrated Nanosystems Development Institute (INDI) group with the IUPUI campus. These are the health sciences, and the renewable energy. Our dedicated faculty and research resources on campus have led to the success of this emphasis. The collaboration of the IU Medical School has added to the future potential of this institute.

In 2010, the team of engineering from ECE and ME together with INDI received an NSF NUE grant leading to the development of a track program within ECE and $\mathrm{ME}$ programs, taking the students for nanotechnology road from the sophomore year to the senior year. Educational outcomes from this track program have been presented elsewhere [1-5]. Unlike the other STEM programs that combine math and sciences into K-12 education [6-8], this development features a multidisciplinary area where a nanotechnology theme is the focus that let participation from ME, ECE, BME, Chemistry, and Physics all into the same program.

\section{ABOUt ThE NANOTECHNOLOGY TRACK}

The team of faculty from engineering and sciences has provided innovative educational opportunities in nanotechnology. With the collaboration with INDI, important features of this program have been integrated into the curricula. This included lab-based curricula; strong linkages to existing undergraduate research programs; technical and research courses; and integrated Themed Learning Communities (TLCs) in nanotechnology. Students pursuing the nanotechnology track will have lectures and laboratory research experiences to prepare them to enter the global workforce and to become leaders of research and development in industry, business, and academia in the emerging era of nanotechnology. The nanotechnology track was designed in a way that will not exceed the plan of study (P.O.S) credit hours meeting the minimum credit hours needed for the ECE or ME degrees. Students may choose four within the allowable elective list "tech electives, EE electives, $\mathrm{ME}$ electives, $\mathrm{CmpE}$ electives, math/science electives, and free electives [9] of their programs.

Students are prepared for the nanotechnology track via freshman engineering courses where TLC "Theme Learning Community" where cohort of 15 students are taking freshman courses emphasizing the future applications of nanotechnology. Some projects in the problem solving freshman course are pursued where some mathematical background are emphasized. The students pursuing this track must have gone through the TLC experience at the freshman year.

The following gives a brief description of each course under the nanotechnology track program. '

\section{A. Introduction to Nanotechnology and Applications 3 credits}

The course aims to help students understand the scale of nanotechnology, identify materials used in nanotechnology, evaluate forces acting in nanomaterials, describe electronic and mechanical behaviors on the nanometer scale, and describe applications in industries and life sciences. Nanoversus micro-technology in the evaluation of potential risks and benefits will be covered with emphasis on their societal impact.

\section{B. Nanosystems Materials and Measurements (Lab-based Course) 3 Credits}

The course introduces students to statistical process control, optical microscopy (light propagation, Snell's law, mirrors, prisms, lenses and beam-splitters, etc), scanning electron microscopy, atomic force microscopy, scanning tunneling microscopy (STM), near-field microscopy, transmission electron microscopy, surface roughness and step profilers, roughness step testing (RST), and reflectometry, and ellipsometry. Nanosystem measurement laboratory is associated with the course.

\section{Nanosystems Principles 3 Credits}

This course introduces students to the principles and applications of nanosystems, including: nanoscale materials, processes, and devices. It also provides students with a basic understanding of the tools and approaches that are used for the measurement and characterization of nanosystems and for their modeling and simulation. Moreover, the course covers the applications of nanosystems in a wide range of industries: information technology, energy, medicine, and consumer goods.

\section{Nanosystems Processes and Devices (Lab-based Course) 3 Credits}

This course introduces students to processes and devices associated with integrated nanosystems. "Integrated Nanosystems" refers to systems which consist of integrated micro-, meso-, and/or macro-scale parts and their core components in nanoscale materials, processes, and devices. The course focuses on the theory and operation of select electronics, electromechanical, and biomedical devices which are used for information technology, sensing, medical, and other applications. The lectures will be complemented by hands-on laboratory experience.

\section{E. Research}

Students are encouraged to pursue research during their undergraduate studies. During the sophomore year, the students are divided into teams to work with faculty mentors, who assign a literature search on a given nanotechnology research topic. During the junior year the students will pursue a research project with their faculty mentor on an assigned research topic. The first course in this track prepares students for a research career in nanotechnology.

\section{THE SOPHOMORE COURSE}

\section{ECE495/ME397: Intro to Nanotechnology and Applications (3 credit hours)}

\section{Required Course for nanotechnology track:}




\section{A. Bulletin Description}

The course introduces students to the scale of nanotechnology, materials used in nanotechnology, forces acting in nanomaterials, electronic and mechanical behaviors on the nanometer scale, and applications in industries and life sciences. Nano-versus micro-technology in the evaluation of potential risks and benefits will be covered with emphasis on their impact on society.

\section{B. Prerequisite or co-requisite}

ECE 204 (for ME major); ECE270 and ECE201 (for ECE major)

\section{Prerequisites by topic}

TABLE I

COURSE OUTLINE

\begin{tabular}{|c|c|}
\hline Lecture \# & $\begin{array}{c}\text { Conversion from Gaussian and } \\
\text { CGS EMU to SI }{ }^{\mathrm{a}}\end{array}$ \\
\hline $1-3$ & $\begin{array}{l}\text { Introduction to nanotechnology: Perspectives } \\
\text { and businesses, and infrastructure }\end{array}$ \\
\hline 4 & Nanotechnology products \\
\hline 5 & Nanotechnology standards \\
\hline 6 & $\begin{array}{l}\text { Environmental, Health and Safety } \\
\text { Aspects of Nanotechnology }\end{array}$ \\
\hline $7-8$ & $\begin{array}{l}\text { Nanotechnology manufacturing: (tools, } \\
\text { molecular assembly, quantum metrology) }\end{array}$ \\
\hline $9-12$ & $\begin{array}{l}\text { Nano electronics (band structure, conductors, } \\
\text { semiconductors, device strategies, CNT, Nano } \\
\text { devices and single electron tunneling, and } \\
\text { molecular wires). Design approach for device } \\
\text { characteristics }\end{array}$ \\
\hline $13-16$ & $\begin{array}{l}\text { Nano-optics (interaction of light with matter \& } \\
\text { Nano-perspective, surface Plasmon, } \\
\text { Quantum dots, } \\
\text { Nano photonics, fabrication and applications). } \\
\text { High efficient quantum dot solar cells, design } \\
\text { approach. }\end{array}$ \\
\hline $17-21$ & $\begin{array}{l}\text { Nano magnetism (introduction, Nano magnetic } \\
\text { materials, physical properties, magnetic Nano- } \\
\text { structures, and Nano magnetism applications) }\end{array}$ \\
\hline $22-26$ & $\begin{array}{l}\text { Medical nanotechnology: medical } \\
\text { breakthroughs, nanoparticles and Nano } \\
\text { capsulation, and stimulating } \\
\text { Tissues and functions }\end{array}$ \\
\hline 27 & Term Paper discussions \\
\hline 28 & Students' presentation \\
\hline
\end{tabular}

Semiconductor devices (pn-junction diodes, BJTs, MOSFETs), digital logic (Boolean functions, logic building blocks, and finite state machines).

\section{Textbook}

Gabor L Hornyak, John J Moore, Harry F. Tobbals, and Joydeeo Dutta, "Fundamentals of Nanotechnology" CRC 2009. ISBN \# 978-1-4200-4803-290000

\section{E. Goals}

Introduce students to the nanotechnology area in various applications, and providing them with research hypothesis as applied to nanotechnology materials and devices. The course was structured to provide a number of research areas that are suited for the engineering discipline.

\section{F. Outcomes}

After the successful completion of this course, a student should be able to:

1) Describe the status of nanotechnology infrastructure and products in the USA in instrumentation, devices, materials, and applications. $[a, b, c, d]$.

TABLE 2

ABET CATEGORY

\begin{tabular}{lcc}
\hline \hline $\begin{array}{c}\text { Engineering } \\
\text { domain }\end{array}$ & Credits & Percentage \\
\hline Science & 2 & 67 \\
Design & 1 & 33
\end{tabular}

2) Compare Nanotechnology to microtechnology issues. $[c, e, k]$.

3) Demonstrate knowledge of Nanotechnology standards, tools, and nanomanufacturing $(a, c)$.

4) Explain the features of nanoscale electronics $[b, c]$. Communicate team project or team research term paper work through oral presentation, and technical report $(b, c)$

\section{Evaluation Methods}

Midterm exams and a comprehensive final exam. Homework assignments and term paper presentation.

\section{SAMPLE RESEARCH PROJECTS}

\section{A. Non-Invasive Diabetes Monitoring Devices}

Monitoring glucose levels using nanotechnology devices "smart Tattoo" that can detect glucose molecules in the absence of enzymes. This emits a florescent color that correlated to the level of glucose. The sensor is based on a plant-sugar-binding protein.

Students studied the current technologies of monitoring glucose levels, and the promising solutions to the invasive issue by allowing new types of nan-invasive blood glucose sensing devices that can utilize other bodily fluids in addition to blood. The research project covers the electrochemical reaction using diffusible or immobilized mediator to transfer the electrons from the glucose oxidase to the electrode. With the use of nanotechnology, however, the electrode is able to perform direct electron transfer utilizing organic conducting materials. This allows for implantable, continuous monitoring devices.

\section{B. Nanotechnology in Bone Regeneration}

This research explores how nanotechnology has begun to impact this future field. There have been many unanswered 
questions there nanotechnology can potential contribute to such important medical fields. Current technology have limited available quantities, inability to possess the same properties as bone, provoking immune system response, infection transmission, and cost. The research also focuses on how advancements in nanotechnology can be applied towards various tissue-engineering strategies. Students study more in regenerative medicine with the development of nanostructures and biomaterials with potential clinical implications. The studies included scaffolds that are biocompatible, extracellular matrix (ECM) in cartilage cells to produce bone, synthetic bioscaffolds.

\section{Nontechnology Applications for Cancer Detection and Treatment}

Research covers new technology for screening for cancer detection from benefiting of biomarkers in tissue and fluids. Quantum dots are a way that enables the simultaneous detection of multiple markers. They are nanoparticles that emit light of different colors depending on their size. The photoluminescence signals from antibody-coated quantum dots can be used to screen different types of cancer. The different colored dots can be attached to antibodies for cancer biomarkers to allow oncologists to discriminate cancerous and healthy cells by the spectrum of light they sea. Carbon nanotubes are a type of nanodevices for biomarker detection. Therefore, biomarker screening can help in cancer detection. Cancerous cells may also absorb the nanocarriers to bring drugs into the cells. The research deals with the methodology of treatment and diagnosis.

\section{Molecular Nano-Communications}

This research studies the nanoparticles and nanowires based sensors since they are utilized in FET devices. The nanowire FET may be converted into nanowire nanosensors for $\mathrm{pH}$ sensing.

\section{E. Nanotechnology Based SOC}

System on Chip is an area where integrated sensor system can be implemented on board for different sensing functions. Some of the designed systems are applied to health care, while others for renewable energy.

\section{RESULTS AND DISCUSSION}

\section{A. Motivation}

The course motivates undergraduate students who are pursuing a career in nanotechnology or sometimes a research career. Since the course is a sophomore course, introducing students to research hypothesis, and teach them how to search to find research activities that have been introduced into this research issues, means of approaching solutions, and limitations of various approaches, the courses gained popularities within the ECE and ME departments. The team work and the multidisciplinary aspects of the projects have enhanced students' motivations into the research.

\section{B. Research Outcomes}

At the end of the semester, four poster papers were presented in a poster research day on campus, where industry representtatives and faculty members from School of Sciences, Engineering, and others have attended and had exchanged research ideas with the students.

\section{Research Integration}

Student contribution was limited to the mathematical models, software development, and simulations. Students had lab tours to the microscopy center on campus and had discussions with the research scientists running these equipment.

\section{Feedback}

The students' feedback on the course contents in the different areas and the research components of the course. All students have reposted very high satisfactory results in all questions regarding the course materials, research topics, course preparation on future research, and their expectation with the course multidisciplinary aspects, the team work, and poster presentations.

\section{CONCLUSION}

The new research course developed at the sophomore year has enhanced the students 'interests in pursuing a future career in nanotechnology. Majority of students are progressing more of nanotechnology courses in their junior and senior years. The new course provides integration of knowledge from math and sciences, and various components from ME, ECE, and BME. The knowledge learned in this course may also assist students with other areas such as DSP, Medical devices, communications, and instrumentations. In addition, the research apparatus involved in this research will assist students in integrated circuit design for both digital and analog applications.

\section{ACKNOWLEDGMENT}

The authors will like to acknowledge the NSF NUE program grant 1042110. Acknowledgements are also due to Mr. Vinay Kumar Suryadevara for his assistance with this paper.

\section{REFERENCES}

[1] Mangilal Agarwal, Maher E. Rizkalla, Sudhir Shrestha, and Kody Varahramyan," " Impact of Nanotechnology Themed Learning Community (TLC) Program in Freshman Engineering," $121^{\text {st }}$ ASEE Annual Conference \& exposition, Paper \# 9570, Indianapolis, IN , June 15-18, 2014.

[2] Mangilal Agarwal, Maher E. Rizkalla, Sudhir Shrestha, Hazim A ElMounayri, and Kody Varahramyan, "Impact of Multidisciplinary Nanotechnology Curricula on Engineering and Science Programs," $2014121^{\text {st }}$ ASEE Annual Conference \& exposition, Paper \# 10093, Indianapolis, IN , June 15-18, 2014.

[3] Maher E. Rizkalla, Sudhir Shrestha, Mangilal Agarwal, Hazim ElMounayri, and Kody Varahramyan, "Impacts of New Modes of Instructions for Nanotechnology Education within Engineering and Science Programs, $120^{\text {th }}$ ASEE Annual Conference \& Exposition, Paper \# 5817, Atlanta, GA, June 23-26., 3013

[4] Agarwal Mangilal, Rizkalla Maher, El-Mounayri Hazim, Shrestha Sudhir, Simpson Jane, and Varahramyan Kody, A Novel for Integrating Nanotechnology Track in Undergraduate Engineering degree Programs, 
Journal of Nano Education, Volume 5, Number 2, December 2013, PP. 135-141 (7)

[5] Maher E. Rizkalla, Mangilal Agarwal, Sudhir Shrestha, and Kody Varahramyan," Integration of Knowledge in Engineering/Science via Nanotechnology Programs, 2011 ASEE Annual Conference \& Exposition, Paper \# AC2011-421, Vancouver, Canada, 25-29 June 2011

[6] P. Seshaiyer, J. Suh, N. Peixoto, M. long, M. Corcoran, V. Grewal, "Inquiry-based approaches in K-12 classrooms to empower the next generation STEM workforce," FIE2014, pp.576-583.

[7] S. B. Nite, J. Morgan, M. Margaret, R. M. Capraro, C. A. Peterson, "Science, Technology, Engineering and Mathematics (STEM)
Education: A Longitudinal Examination of Secondary School Intervention," FIE2014, pp.1382-1388.

[8] D. Fehlinger, Jr., J. Ward, and A. Fontecchio, "Increasing 11th Grader's Interest in STEM Majors via a NAE Grand Challenge: Securing Cyberspace-Themed Project," FIE2014, pp.1686-1688.

[9] http://www.engr.iupui.edu/departments/ece/ 